Marquette University

e-Publications@Marquette

College of Communication Faculty Research and

Publications

Communication, College of

4-1-2015

Brave Sperm and Demure Eggs: Fallopian Gender Politics on YouTube

Pamela Hill Nettleton

Marquette University, pamela.nettleton@marquette.edu

Published version. Feminist Formations, Vol. 27, No. 1 (Spring 2015): 24-45. DOI. (C) 2015 Johns Hopkins University Press. Used with permission. 


\title{
Brave Sperm and Demure Eggs: Fallopian Gender Politics on YouTube
}

\author{
Pamela Hill Nettleton
}

A narrative analysis of videos of human conception from medical and nonmedical sources aired in the democratic space of YouTube finds that stereotypical gender roles are consistently assigned to cellular behavior. Sperm are represented as little men and embodiments of hegemonic masculinity, with heroic sperm winning the egg prize after a competitive athletic contest fraught with peril. Eggs are represented as featureless planets floating in a murky void and are without agency or action. Almost every video is about the "journey" or "adventure" of the sperm; the egg has no adventure. These videos represent a view of a persistent gendered narrative of human fertilization that does not coalesce with emerging scientific narratives that appear to attempt to be more gender-neutral in accounts of conception. The imposition of gendered social scripts onto biology_even pop-culture biology_may work to obscure common understanding of the nature of gender and of humanity, as well as reveal vivid and enduring stereotypes.

Keywords: conception / feminism / fertilization / human egg / Martin, Emily / reproduction / sperm / YouTube

\section{Introduction}

In 1992, anthropologist Emily Martin argued that medical-textbook discourse anthropomorphized the behavior of sperm and egg, constructing a "romance" between the cells that was based on stereotypical male and female gender roles in Western society. Martin's work inspires this new media update: an analysis of the sperm and egg behavior depicted in YouTube videos about human conception. This turn from Martin's work with print textbooks to studying online, 
audience-generated content recognizes the pedagogical role that digital media plays today, and the centrality of digital media in daily life. Other scholarship examines gender-equity issues in formal sex education and education in general (DeLamater 2007; Klein I988; Klein et al. I994). This study adds to that work and offers an additional, complementary perspective about gendered narratives of the human body as presented in new media.

In this narrative analysis, thirty-two YouTube videos are categorized, organized into themes, and analyzed for key messages and attitudes. These representations provide a view into a persistent, gendered media narrative of human fertilization, in contrast with emerging medical research and current textbooks, which appear to no longer present the stereotyped accounts found by Martin. This analysis contributes to feminist media studies by documenting the intensity of the stereotyping of gametes in these videos. Assigning gendered roles to sperm and eggs works to essentialize male/female social roles as being biological and intractable from the very moment of conception. The mix of scientific information with gender stereotypes present in these videos helps stereotypes masquerade as fact and serve to shore up claims that irrefutably gendered biological imperatives exist.

\section{What This Study Does}

This study examines popular culture accounts of conception available on YouTube between August I5, 2010 and August 15, 20I3. This qualitative narrative analysis of thirty-two videos examines how gender is represented in depictions of sperm and egg behavior during fertilization. This work is situated within the body of feminist media studies, and within the cultural studies perspective of Stuart Hall's (I975, I988, I992) theories of media representation and of the power of the absences in representation. This study is also positioned in relationship to the gendered science work of Londa Schiebinger (I989, I993, I999, 2003, 2008), Robert N. Proctor and Schiebinger (2008), Sarah S. Richardson (2008), Margaret W. Conkey (2008), and others.

This study addresses these research questions:

- More than twenty years after Martin's (I992) study of print textbooks, do new media digital representations on YouTube reflect similarly gendered narratives of conception?

- What representations of sperm and eggs exist in the digital media of YouTube, and what might those characterizations mean?

- What characterizations and representations of sperm and eggs are absent, and what might those absences mean? 


\section{Literature Review}

Feminist science studies connect science and culture and demonstrate that they do not exist independently of each other. Donna J. Haraway (I989) warns against practicing the "God-trick" — acting as if knowledge arrives from a place outside the world, untouched by gender stereotypes or culture. Scientific understanding of human bodies exists alongside, not outside of culturally determined scripts. Scientific truth is "sculpted by the social milieu in which biologists practice their trade," argues Anne Fausto-Sterling (2000, 5). The cultural soup in which we all swim cannot help but influence the ways in which scientists think and reason, even when those scientists make honest attempts to evaluate observations without preconceptions.

Social and cultural stereotypes have an effect on science, and science is not neutral in matters of gender and race (Schiebinger 2008, I4). Jill A. Fisher (20II) describes science as "an institution comprised of individuals who are making decisions about what questions are important, what methods are valid, and how results will be analyzed. . . . what scientists observe is often subject to what they already believe is true and is usually in sync with broader society's culture and values" $(2-3)$. Cultural gender bias can affect science, and questioning and destabilizing long-standing gender assumptions may open doors to new perspectives and insights (Conkey 2008; Schiebinger 2008). For example, Conkey points out that when archaeological evidence is examined and considered, the roles and interactions of modern-day men, women, and children color the archaeologists' interpretations of their findings, and ancient family life is imagined to echo current family life (58).

Critiques of the gender biases of science argue that unchallenged assumptions about gender or a failure to consider it can slow the formation of alternate theories and hamper objective thinking. Social narratives of gender stereotypes may become so naturalized that scientists fail to critique their own biases or explore alternative reasons for what they are observing. Interpretations of biology that are gendered or aligned with particular social scripts can create flawed science, delaying or misguiding enhanced understanding (Proctor and Schiebinger 2008).

Imposing stereotypical social scripts onto media about science, such as these YouTube videos about human reproduction, has consequences. Assigning gender roles to cellular behavior makes attitudes and behaviors appear to be born in the DNA and inescapable. If cells are seen as having distinct male and female behaviors, then stereotypical gender roles appear natural and essentialized. If, as Mary Douglas (I966, I9) argues, "the body provides the basic scheme for all symbolism," then how bodies are described and represented in popular culture takes on ideological meaning. Characterizations of human reproduction in print and digital media can impact, reinscribe, or resist stereotypical gender attitudes. In Martin's (I992) examination of imagery and metaphors in biology 
textbooks, she finds menstruation characterized as unproductive and wasteful, described by words like "ceasing," "dying," "losing," "denuding," and "expelling." In contrast, male reproductive physiology is characterized as productive, and the "sheer magnitude" of sperm is described, not as wasteful, but as "remarkable" and "amazing." Females "shed" eggs, males "produce" sperm. When it comes to sperm, leftovers that do not become babies are not considered to be waste products that were fruitlessly expelled; however, eggs are described in just this way. Martin finds that the egg is described as passive and inert; it does not act or move, but "drifts," is "transported" or "swept along." Sperm are described as "strong," "energetic," "vigorous," and on a "mission" to "bombard," "burrow into," and "penetrate" the egg.

In her history of sperm, Lisa Jean Moore (2008) finds that the single cells are assigned both biological and social meanings that reveal attitudes about gender. She notes an anthropomorphizing of individual cells, treating sperm as if they have conscious motivation and sentient agency: "It is almost as if some men wish to retain an idea that the sperm commandeers a man's body and that the sperm's 'drive' compels men to behave in particular ways" (37). Ideas of stereotypical, nostalgic masculinity drive theories of sperm competition, and these not-very-scientific "theories" are sometimes used to shore up patriarchal structures.

Feminist media studies demonstrate a powerful connection between media representations of gender and the social reality of it, and YouTube videos are mass media. Media reflect social and cultural values, but even more importantly, they shape them. Lana F. Rakow (200I) argues that "media texts do not present messages about our culture; they are culture" (42; emphasis added). Popular media act as socializing agents, educating audiences in their place in society (Ferguson, Kreshel, and Tinkham I990; Garner, Sterk, and Adams I998). Edward Herman and Noam Chomsky (I988) identify mass media representations as having the power to teach social values and beliefs to its audiences.

Mass media play an important role in producing hegemonic masculinity and reinforcing patriarchal ideology (Hanke I998a, I998b; Rakow 200I). In media, domination and exploitation of women are so common they become expected, and the depiction of young men as violent and angry is typical (Prushank 2007). When media represent violence and competition as existing naturally in men, men appear to be essentially helpless against their own biology and are given a pass when it comes to violent behavior, including violence against women (Nettleton 20II). Such narratives of boys and men contribute to constructing traditional, violence-linked ideas of masculinity (Consalvo 2003; Katz I999; Kimmel 20II). Media narratives are important forces in shaping social and cultural attitudes and may offer insight into current cultural production of ideas of gender. 


\section{Theory and Method}

This narrative analysis combines critical cultural studies with feminist theory to consider the intersections of gender and hegemonic media representations in YouTube videos. Narrative analysis identifies common themes across related texts that, taken together, create social and cultural meanings, norms, and values (Cloud 1992; Condit 1989; Fiske I987; Hoerl and Kelly 20I0). Narrative analysis focuses on how a story is told, and, following Hall, this study also focuses on how a story is not told. An analysis is made not only of the texts but also the silences and absences in those texts. Both George Gerbner (1972) and Gaye Tuchman (I978) label a group's lack of representation in media as an act of social and cultural annihilation. Lisa M. Cuklanz (2000) argues that this annihilation can be quite political, and that the silencing of voices is a first step in opposing them. Absences can be useful in revealing assumptions and naturalized attitudes. Hall's (I992) work recognizes the profound importance of identifying what is missing from media messages: "We had to develop a methodology that taught us to attend, not only to what people said about race but . . . to what people could not say about race. It was the silences that told us something; it was what wasn't there. It was what was invisible, what couldn't be put into frame, what was apparently unsayable that we needed to attend to" (I5; emphasis in original). This analysis connects common narratives across the sample of YouTube videos and also comments on the absences common in those texts.

YouTube is a space in which videos produced by amateurs and professionals, medical people and high school students, receive democratic exposure with popculture accessibility. Free of media gatekeepers and editors in a medium open to a large pool of amateur and professional media producers, YouTube offers a view into popular cultural narratives. The YouTube website, in existence since 2005 and owned by Google since 2006, shares user-generated video content with 800 million unique visitors each month (Seabrook 20I2). Registered users can upload content, and unregistered viewers can view videos. Some sixty hours of videos are uploaded every minute (Oreskovic 20I2; Richmond 20II), mostly from individuals, but also from corporations, institutions, and media outlets. Jean Burgess and Joshua Green (2009) describe YouTube as "a force to be reckoned with in contemporary popular culture" (vii). YouTube is the premiere massdistribution hub for video content (Jones 20Io).

Since it is commercially viable and seeks media partners, it can be considered "mass media" (ibid.). But whether or not it should be considered a democratic space is contested. Aaron Hess (2009) argues that YouTube is too playful and participation too capricious for it to serve as a site for serious democratic discussion. José Van Dijck (2009) might have found YouTube to be democratic in content when it was a small startup, but now characterizes it as "a commercial platform that is now an important node in an evolving ecosystem of media conglomerates dominated by Google" (54). Videos uploaded by media 
producers can be taken down if found in violation of music or other creative copyrights. Accounts can receive "strikes" against them, and sometimes content can be removed by YouTube if videos are found to contain hate speech, cyber-bullying, harassment, threats, child endangerment, content that YouTube judges as "harmful" or "dangerous," certain types of spam, and certain types of violent content (YouTube 20I0). According to the YouTube website, these censorship decisions are made by the "YouTube Team" according to YouTube's own rules and "community guidelines," which could, depending on the decision and the context in which decisions are made, be judged to be democratic or not-so-democratic. The concept of do-it-yourself media production and distribution creates a media environment not merely consumed by audience members, but also created by them, which adds significant dimensions of individual freedom and democratic participation to a mass-media outlet (Benkler 2006; Knobel and Lankshear 20I0). In their study of YouTube video memorials to fallen soldiers, Britt K. Knudsen and Carsten Stage (20I3) conclude that YouTube offers an interactive, sociopolitical space in which the audience can both create media and comment on the creations of others, and they label this "democratized" (432). Allowing for the monitoring processes that may not be thoroughly democratic in some cases, YouTube is considered a democratic space for the purposes of this study because it has numberless online points of access in which instructional videos, homework assignments, marketing materials, and entertainment are created and shared by scientists, teachers, students, and the general public. Anyone with network access can upload videos and anyone with network access can view them, provided that they are in a country that allows unfettered access to the internet and YouTube.

With YouTube videos, there are limitations and challenges to sampling texts or conducting content analysis. Content changes minute by minute, and it is impossible to pause and measure it quantitatively in any enduring manner. Digital video content readily allows sharing and "grabbing" of images from other media, clouding the meaning of any clear count of original material. Media producers may take down, alter, or rename their posted media (and themselves) at any time. Even in the instances when the producer of the video appears on camera, it can be difficult to ascertain how the producer self-identifies in terms of gender. Video producers identify themselves by self-chosen names, many of them nonsensical and genderless: for example, SuperPikaGrox, bEx3d, SerenityNightwind69, Mbarsoor, GoldenTusk. A few appear to be proper names or include a reference to gender-Nachiket Bhujbal, Hateworkboy, ReyMan2oio-but even so, there is no explicit statement of gender that is definitive, so a meaningful examination of videos in light of the gender of the producer would require too much guesswork to be reliable.

Recognizing these limitations, 700 texts were initially identified by using the search term sperm and egg. My review occurred between August I5, 2010 and August 15, 2013, beginning with the most-viewed and continuing down to 
lesser-viewed videos. It quickly became obvious that there was much repetition of content and that, in some cases, the same video (or large chunks of it) was reproduced under various titles. Duplicates and irrelevant videos were culled from the list, and ultimately thirty-two YouTube videos were compared and analyzed. Among the eliminated videos were excerpts from three full-length television documentaries because these were not available in their full form and they seemed more suited to a study of television documentaries.

Twelve fields of information were recorded: video title, producer, length, uploading date, number of viewings, music, the sperm's behavior, the egg's behavior, the sperm's appearance, the egg's appearance, and the language of any narration and written text. These results were analyzed for common themes, compared to current understandings of the actual science of fertilization, and evaluated in light of feminist media theories of representation.

In future research of popular media representations of human fertilization, film and television would be meaningful texts to explore. An examination of the dimension of race in these and other representations also deserves scholarly attention, as the animation in this study (and perhaps around this topic universally) occurs inside the body and does not overtly comment on race. And, expanding this study to a larger sample and updating it with the ever-growing catalog of YouTube videos would be two more directions for future research.

\section{Findings: Themes}

Videos were posted between February 2006 and July 2013 and range in length from eleven seconds to ten minutes, ten seconds. The number of viewings of the thirty-two videos range from 643 to 863,709 . Producers self-identify as medical corporations, biology students, and individuals with no other stated affiliation. Most videos include music soundtracks; two are narrated. Many spell out words in animation or written placards, usually used to identify parts of the cells.

About half of the videos use biological terminology and are meant to present at least some scientific information about fertilization. Most of these appear to be the work of high school and college students for biology courses and bear introductory slides or labels with course numbers; others are produced by commercial organizations, such as fertility clinics or, in one case, Parents magazine. In these, scientific terminology is often mixed with colloquial or humorous language and animated with candy figures, claymation, rustic drawings, or sophisticated artwork. The significance of the content of videos made to communicate scientific information is more weighty than that of videos made to entertain - although both shed light on the kinds of representations of sperm and egg that are commonly accepted. To help distinguish this difference, the analysis of videos identified as "scientific" is identified separately below. The other half of the videos employs no scientific language and is primarily dramatic 
or humorous, with animation ranging from rustic to professional. These appear to be created by individuals for reasons that cannot be identified, since there is no written claim in the video, or in the information about the video, that links the text to any sort of science course or scientific purpose. The line here is fuzzy; some of these may have been made for school projects, but they are not identified as such and it is impossible to know the reasons for their creation. Two of the thirty-two videos include religious commentary, explaining the process of fertilization as being miraculous and part of God's plan.

From the narrative analysis, prevalent themes of representations of human conception on YouTube videos were identified and are summarized here. A detailed analysis follows this summary. The action, focus, narrative, and outcome are all about the sperm cell; in these videos, the egg is almost always ignored, and whatever happens to it in the fertilization process is not commented on. The sperm are described as being amazing and extraordinary, endowed with impressive skills and powers; the egg is rarely described at all, and is never referred to as being amazing or powerful. Sperm are described as being brave when faced with the obstacles presented by the female body, which is regarded as being dangerous and life-threatening for the sperm. Sperm are also anthropomorphized and given facial features, as well as characteristics of hegemonic masculinity like bravery and athletic ability; eggs are rarely anthropomorphized, almost never have facial features, and are not so much characters in a narrative as they are geographic goals for the sperm. Sperm are active heroes in these video narratives while eggs are passive objects with no agency. The point of view in these videos - the camera angle of fertilization - is that of the sperm's-"eye" view, never that of the egg's. Sperm behavior is represented as being competitive, violent, and militaristic toward one another and toward the egg, and these qualities are praised as virtues. Fertilization is ultimately portrayed in ways that echo violent sex, rape, or colonization, with the sperm attacking the egg, often with weapons.

Among all thirty-two videos, eight prevalent themes of representations were identified as follows:

\section{It Is All About the Sperm-Nothing Happens to the Egg}

Sperm are depicted as embarking on a treacherous journey through the vagina to the fallopian tube and the egg, but the egg's journey from the ovum into the fallopian tube and onward to the uterine wall is never mentioned. Examples of video titles that reflect the action the sperm is taking and do not discuss what is happening to the egg are: "The Great Sperm Race" (SuperPikaGrox 2009); "Sperm Attack" (Robholio 2008); "Sperm Race" (Shibad 2009); "Sperm Rider: Quest for the Sky Egg" (BarfQuestion 2007); and "Swim of the Sperm" (Redsandro 2006).

Some scientific videos have titles that reflect the process: "Fertilization (Conception)" (Nucleus Medical Media 20I2); "Human Fertilization" 
(Teencompanion 2008); and "Reproduction" (Chichin85). However, other scientific video titles focus on the sperm alone: "ooSperm" (Mbarsoor 2007); "3D Sperm Fertilization Project" (Armyofdarzmonkeys 2007); and "Human Guinea Pigs—Sperm Race” (Guineapigs 2007).

\section{Sperm Are Amazing; Eggs Are Merely Present}

In a video that presents its information as evidence of God's hand in human reproduction, sperm are described as being amazing, remarkable, and even "miraculous," with a "powerful engine" and the ability to race "as fast as a speed boat" heading for the egg in "an expert manner" (Againstfitna 2008). In a scientific video, sperm have a job; they "need to work out where the nearest fallopian tube is" (Guineapigs 2007).

The egg is not depicted as having a "job," a role, or anything at stake in the process. In scientific, nonscientific, and religious videos they are never described as being amazing or miraculous or clever. In fact, eggs are almost never described at all. Fertilization is not represented as a victory or achievement on the part of the egg; the moment of fertilization is depicted as having happened only to the sperm. The sperm is a person, a little man. In scientific videos, the egg is a "coveted target" (Parthenon Medical 20I2), a "goal" (Mbarsoor 2007), and a "prize" (Goldentusk 20I2).

\section{Sperm Are Brave; the Vagina Is Dangerous}

Even in scientific videos, sperm are described as brave, vigorous fighters who enter the frightening and threatening vagina where death lurks around every corner, and many of these animations depict vaginas that possess inexplicable and biologically incorrect twists and turns. The sperm are on a "mission" that is "extremely difficult and requires much strength and speed" (Mbarsoor 2007); the sperm's "difficult journey" is rife with "lethal dangers" (Againstfitna 2008), a "perilous journey against incredible odds" (Nucleus Medical Media 20I2) filled with "obstacles to Mr. Sperm" (Akaraoo5 2009). Only one video describes sperm in nonheroic terms, saying the amount of sperm is a "teaspoonful" and that "most sperm will lose their way" (Parents 2012).

Scientific videos also characterize the vagina as a dangerous place where sperm "will all be drowned . . . a burial ground" (Goldentusk 20I2). The natural chemistry of the vagina is characterized as "acidic" and "fatal," where sperm "get trapped or die" (Nucleus Medical Media 20I2). A woman's body can "comfortably destroy all the sperm who enter," but "God created precautions against the mother's dangers" (Againstfitna 2008). Carnage is everywhere: "Within a few minutes, the walls of the womb are coated with dead sperm" (ibid.). In one video, sperm sing "I'm going to die," while fellow sperm scream in the background as they crash and explode against the vaginal walls; the video concludes with a shot of a plaque reading "In loving memory of all those we have lost" (Goldentusk 20I2). 


\section{Sperm Are Little Men; Eggs Are Featureless Planets}

Sperm usually have faces; eggs are almost always featureless planetoids. In nonscientific videos, sperm have eyes, eyebrows, and mouths (bEx3d 2008; Robholio 2008); they wear clothing, such as top hats, caps, bow ties, and boots (Condomz 2006; Hateworkboy 2008; Redsandro 2006; Robholio 2008), and carry accessories, such as a briefcase of twenty-three chromosomes (Redsandro 2006). Sperm carry concealed weapons as well, producing a sledgehammer, drill, gun, and bomb to fight off other sperm and penetrate the egg (Robholio 2008). Sperm wear racing helmets, glasses, and have tongues that hang out from the exertion of swimming (Maaxxximo 2007). In a scientific video produced by a fertility clinic, blue bow ties and pink hair bows distinguish gender in sperm and egg cells, and one egg has large red lips (Parthenon Medical 20I2).

In scientific (Armyofdaizmonkeys 2007; Izzo 2009) and nonscientific (Vadg 2009) videos alike, sperm glow as if they were made of neon or radioactive material, bringing light to the ominous-looking black void of the vagina. The vagina and fallopian tubes often appear as vast expanses of dark space, the egg floating there as if it were a planet—and it often resembles one, drawn as a featureless globe in both nonscientific (Redsandro 2006; Robholio 2008; Shibad 2009; Vadg 2009) and scientific (Nucleus Medical Media 20I2) videos. It resembles a clumsily made ball of clay (SerenityNightwind69 2007) or a prickly death star (Againstfitna 2008). In a few videos, the egg is literally egg-shaped (although a human egg is round); in a nonscientific video, it is decorated in stripes like a painted Easter egg (Goldentusk 20I2). The first glimpse of the egg is signaled in many videos with ominous bass thrums in the soundtrack as if it were a movie villain.

In only three videos does the egg have facial features. One is in a scientific video where the egg is drawn with no eyes and oversized red lips (Parthenon Medical 20I2). Among nonscientific videos, one presents an egg that looks at the sperm bouncing off it with irritation (Soaringxh3n 2006), and the other depicts a sperm planting a US flag into a featureless globe of an egg when a face suddenly appears on the egg and says "Ow!" (ReyManzoro 2007).

\section{Sperm Act; Eggs Wait}

Sperm swim, compete, fight one another, plan for success, and travel through dangerous terrain; they take action and are presented as sentient decisionmakers rather than single cells. Sperm are shown as moving in ways that depict personality and motivation, twitching their tails, turning in confused circles, putting their heads together in consultation, and rearing back on their tails like startled snakes. In a video advertisement for gambling, one sperm whips its tail like a soccer player kicking a ball and bats the egg out of the scene (Israelicommercials 2008). The egg is most commonly depicted as immobile, in a state of inert stasis. 


\section{The Point of View Is the Sperm's, Never the Egg's}

The point of view of almost every video- the view of the camera-is that of the sperm looking at the vagina, fallopian tubes, and eggs in a sort of "sperm gaze," following Laura Mulvey's (I975) "male gaze"; one nonscientific video is even titled "A Sperm's Eye View" (bExzd 2008). No video shows fertilization from the point of view of the egg watching the sperm approach. In a scientific video, the "camera" follows along with the sperm, and sometimes even appears to be on top of the head of a sperm, traveling through the vagina (Izzo 2009). One exception is the "Sperm Meets Egg" video produced by Parents (20I2), the only one to include anything of the egg's experience in fertilization. Rather than referring to a "sperm army," it references a "teaspoon of sperm" being involved in the process, and says that "most sperm will lose their way" rather than perish and die. However, the narrator does refer to sperm "penetrating" the egg.

\section{Sperm Behavior Is Competitive, Violent, Warlike, and Militaristic}

Sperm—single cells capable of producing either a male or female child—are portrayed as if they were all men-hegemonic, masculine men, who are militaristic, aggressive, violent, and competitive. A nonscientific video titled "Sperm Attack" characterizes conception as a military invasion involving weapons (Robholio 2008). Sperm are envisioned as martial warriors on a dangerous quest or mission, marching or swimming in formation and working in teams. Even in scientific videos, sperm are arrayed in "armor," are "machines," and carry "valuable cargo" on their journey "fraught with danger" (Againstfitna 2008; Nucleus Medical Media 20I2); they are depicted as mechanical objects built by robots on an assembly line and comprised of many moving metallic parts (Againstfitna 2008).

In nonscientific videos sperm compete athletically, kicking, punching, shooting, racing against, and eating one another (Maaxxximo 2007; Robholio 2008). In "Why Use a Condom," an impatient sperm, a cigarette dangling from its mouth, calls other sperm "losers," threatens to make a baby that will play with matches and "crash Daddy's car in a joyride," and races on ahead, saying "I'm the bad one!" (Condomz 2006). In "Sperm," a frightened sperm with bulging eyes struggles to escape a giant sperm with red eyes and angry eyebrows that is eating up other sperm (Maaxximo 2007).

In scientific videos, sperm are "in search of the egg" and "vigorously trying to penetrate the egg wall"; the egg is "waiting for fertilization" (Teencompanion 2008). "Successful" sperm move "swiftly and vigorously," and "lazy sperm are left behind"; one sperm tells another "I will beat you!" (Parthenon Medical 20I2). Sperm are characterized as "succeeding" or "failing" and dichotomized as being either strong or weak (Againstfitna 2008; Condomz 2006; SerenityNightwind69 2007). The sperm's "success" is worthy of "congratulations" (Shibad 2009). A competitive view of fertilization is clear: "Few if any make it to the ultimate 
prize," says one video (Guineapigs 2007); another calls "second place a loser" and says that "only one can win and claim their prize" (Goldentusk 20I2). There are echoes of colonization and picturing the egg as territory, as in the nonscientific video of a sperm planting an American flag into an injured egg (ReyManzoro 2007).

\section{Fertilization Echoes Courtship-or Rape}

Fertilization is depicted as if it was courtship, sex, or rape. The sperm cells are characterized as men, the egg cell as a female, and the interaction between them is represented as sexual intercourse-and not necessarily consensual. In one nonscientific video, the sperm plants an American flag into an egg, and the egg suddenly has a face and complains about the pain (ibid.). In another, the sperm tries a drill, then a jackhammer, and finally a stick of dynamite to enter the egg, and once inside, lights a cigarette and relaxes, its eyes half-closed (Robholio 2008). In the video "From a Sperm to an Egg-with Love," one sperm edges out another by presenting a rose to the egg (Vadg 2009); and in "Swim of the Sperm," the sperm unpacks a professional-looking briefcase of chromosomes (Redsandro 2006).

Scientific videos employ similar tropes. "I have an eye for the most gorgeous eggling . . . I'm ready to hit on the eggling," says a sperm (Parthenon Medical 20I2). The chemical reactions of conception-the dissolving of the outer layers of the sperm head and the egg, for example — are described as the sperm "cutting through" (Bhujbal 20Io), "penetrating" (Parents 20I2), "piercing” (Againstfitna 2008; Mbarsoor 2007; Teencompanion 2008), and "Mr. Sperm [successfully] cleaves a path [to] Miss Oocyte” (Akaraoo5 2009).

\section{The Absences of Representation}

The absences within representations of human conception are also noteworthy. No narratives of fertilization present the point of view of the egg or tell the story of what occurs to the egg before, during, or after fertilization. The considerable cellular action and division within the egg immediately following fertilization is never addressed. Almost no narratives depict fertilization as a nonviolent encounter between sperm and egg or as a cooperative or even neutral biochemical process with no aggressor or victim, and none address the role of chemicals produced by the female's body that help attract and increase the motility of the sperm.

\section{How Babies Are Made-Really}

In evaluating the narratives of these YouTube videos it may be helpful to have a rudimentary understanding of the current status of scientific representation about human fertilization. Not all of the videos in this study aim to communicate scientific knowledge, but videos that seem to be created for entertainment 
and those created to communicate empirical knowledge share in containing some degree of enduring stereotypes about fertilization. Even when videos appear to have been created for a biology or other science class, gender stereotypes are inserted into the scientific information. This durability of gender stereotyping is striking, particularly in comparison to the gender-neutral accounts in at least some of the current medical texts and recent research in fertility, which appear thoughtful about not reproducing the types of narratives that Martin found in 1992. The tenacity of the stereotype that a sperm is the sole actor in fertilization is particularly interesting when compared to the recognition in current literature of the active role of the egg and the female body in conception (Edmonds 20I2; Zuccarello et al. 20II).

Sperm swim several millimeters per second, but they are assisted by contractions of the uterine walls and fallopian tubes; uterine contractions "propel sperm to the tubes within 5 minutes" (Hacker, Gambone, and Hobel 2009, 42). Cells around the egg secrete chemicals that attract, draw in, or guide the sperm. A chemical is expressed in the oocytes (eggs) and endometrium (lining of the uterus), and it is present in the fluid in the follicles (tube-like structures from uterus to ovary); a receptor for this chemical exists in the heads of spermatozoa (Zuccarello et al. 20II). These chemical reactions are called chemotaxis and help bring sperm to the egg. Sperm are further assisted by other chemicals produced by the female body that trigger hyperactivity and make them move more quickly, called chemokinesis (Ralt et al. 1994). The sperm head attaches to the egg in an adhesion process, and the sperm and egg membranes "fuse, forming an opening into which the sperm nucleus, mid-piece, and most of the tail sink into the egg cytoplasm" (Jones and Lopez 2006, 242). The changes that then happen to the female body are described in Dewhurst's Textbook of Obstetrics and Gynaecology as "strongly proactive, not reactive" (Edmonds 20I2, 5).

While a meaningful discourse analysis of the language in a large number of medical textbooks and literature on human reproduction is beyond the scope of this study, it can be seen that fertilization is characterized in current science as a cooperative process, with both female body and the egg cell possessing agency. Such cooperation and mutual agency is unrecognized in these videos, thus demonstrating the tenacity of gendered narratives regarding conception.

\section{Discussion}

This sample of thirty-two YouTube videos on human fertilization reflects the gendered narratives of conception that Martin found to exist in medical textbooks in r99r. Changing cultural mores and Martin's work may have impacted medical texts over the past two decades; such a finding is beyond the scope of this study, but the few recent medical textbooks and current research included here take pains to describe fertilization without resorting to cultural stereotypes of gender. Despite this shift in medical literature, popular narratives 
as represented by these videos demonstrate the enduring vigor of the highly gendered, anthropomorphized, and courtship/rape narrative of fertilization.

What Martin found happening in medical texts more than twenty years ago is still present today as current commonsense on YouTube. Ideas of hegemonic masculinity and femininity are imposed on the science of human conception. This sort of imposition is important because social and cultural consequences may be significant, obscuring understanding of the actual science in favor of perpetrating selected social scripts. Martin argues that "by becoming aware of when we are projecting cultural imagery onto what we study, we will improve our ability to investigate and understand nature. Waking up such metaphors, by becoming aware of their implications, will rob them of their power to naturalize our social conventions about gender" (I99I, 50I).

Stereotyped and gendered representations of the single cells of human conception are rife not only in nonscientific videos that may be intended only to entertain, but in scientific videos that are intended to educate as well. The mix of scientific terminology and colloquial language about dating and romance in these scientific videos is troubling; the science implies that everything in the video is scientifically sound, imparting a validity to cultural attitudes and prejudices. This is particularly significant in two ways: first, in videos created as classroom assignments, the free mix of scientific information and gender stereotypes reveals an attitude that such stereotypes are light-hearted and bear no significant consequences; and second, YouTube may function as an increasingly important site of information about conception, particularly as sex education is discontinued and/or minimized in public school. Only twenty-two states and the District of Columbia require sex education in public schools, and only nineteen states require that it be "medically, factually or technically accurate" (National Conference of State Legislatures 20I4). With limits on public-school sex education, what YouTube "teaches" matters, and if content blends science with gender stereotypes, accuracy is sacrificed to ideology.

Present in all these themes is the common approach of anthropomorphizing the cells, particularly the sperm cells. In these videos sperm are men. Never mind that sperm also create female humans; sperm embody masculinity and are men in miniature. The egg either embodies nothing or else is represented as a woman. Hegemonic masculinity is represented here as inescapable destiny because it exists even on the fundamental cellular level. Only one kind of sex cell is a real person.

Fertilization is represented as an experience that belongs to the sperm alone, with nothing of note occurring to the egg. This symbolically erases the egg's, thus the female's, role in reproduction, privileging the role of the male; it places a higher value on the sperm than on the egg and recognizes the former as the actor in a process that involves the egg only as an objective or prize. In telling the story of human reproduction, the drama here centers on what happens to the sperm and all else is minimized, ignored, or overlooked. This appears to 
position the male as the only "person of interest" in conception and denies the female any voice or role at all.

Describing sperm as amazing, powerful, and crafty while ignoring the egg allows biology to foster misogyny, especially when sperm are treated as hegemonically masculine beings. Descriptions of sperm as having jobs, missions, and treacherous tasks to undertake on their way to fertilization are in sharp contrast to the lack of description of anything of value that the egg might be bringing to reproduction. Representing fertilization as an act that happens only to the sperm renders the egg, and the female who produces it, powerless in the process of reproduction and the social and political decision-making related to it. Narratives of the dangers that the female body poses to the male body's sperm work to position sperm and egg, male and female, as enemies; when the vagina is portrayed as endangering the sperm, then the violence perpetrated by the sperm becomes justified. Sperm must survive the dangers of entering the female body and fight to conquer or beat or attack the egg-with weapons of destruction, if necessary. This characterizes male rage at women as being inherent at the cellular level.

By rendering sperm as little men and eggs as impersonal floating planets, these video narratives work to position men as being in control of reproduction. Sperm have faces; the egg has no face. Viewers root for the sperm because each one is a "person," but the egg is denied a personality or identity. While standing in for all women and feminine biology, the egg is literally denied a face-denied humanity and individuality. Sperm are plucky little fellows, and it is sad when they perish; eggs are inert, lifeless planets without agency, movement, or the ability to inspire compassion. It is not difficult to extrapolate how these commonly held narrative structures might influence attitudes toward contraceptive politics and healthcare.

This depiction of active sperm and inert eggs echoes aging social scripts of proactive males and reticent, passive females. Despite science that proves how female biochemistry helps guide sperm to the egg, and despite scientific understanding of how egg and sperm act together to dissolve cell membranes and bring the chromosomal material together, the story of reproduction in these YouTube videos is told as though the female's contribution is simply to be a receptacle for male action.

The "sperm gaze" of these representations additionally nullifies the role of the egg and the woman in reproduction. Since anthropomorphizing the sperm and egg cells is such a popular tendency overall, it is particularly striking that an engaging and dramatic story of fertilization is never told from the egg's point of view. Just as the cinematic camera privileges the male gaze (Mulvey I975), so also does the animation in videos described in this study privilege the sperm gaze. There is but one perspective of human conception, and that perspective belongs to the male.

Representing sperm as little soldiers arrayed in armor, swimming in formation, undertaking missions, and fighting to win works to position men as being 
violent in their very cellular structure. This also naturalizes violence against women, and violence in general, as masculine biological imperatives. The rape narrative is particularly troubling. Scientifically, fertilization is a series of chemical interactions among cells; it might be described as "collaborative," or at least neutral. However, these video narratives repeatedly impose sexualized and gendered behaviors onto these single cells. These representations are extended into violent behaviors, and sperm cells are depicted as miniature rapists. The rape narratives are reinforced by describing the sperm as "piercing," "thrusting," "drilling into," "bombing," "cracking," and "conquering" the egg, when in reality the sperm cell adheres to the surface of the egg, the cellular membranes between the two cells are dissolved, and the genetic material of the sperm is absorbed into the egg. It is also troubling that these rape narratives are treated playfully, humorously, and dismissively, minimizing the experience of the victim and privileging the agenda of the attacker.

Missing is any narrative describing the adventure of the egg or taking its point of view, thus suggesting that no remarkable biology is at work there. The egg's physical journey from ovary to fallopian tube and hence to the uterus is entirely overlooked. Without the sperm, it suggests, the egg has no adventure; nothing meaningful happens to the egg until the sperm arrives. This serves to essentialize retrograde sexual and social politics. What happens in the moments and even months following conception is not included or referenced. Conception is treated as a sexual act that is over when the male reaches his climax or goal; nothing meaningful occurs to the egg and nothing meaningful results. Also absent are alternative narratives of conception that are not violent or one-sided, or that are more in line with the actual science of conception. No narratives depict the process of fertilization as a cooperative one among cells, with no aggressor or victim. Finally, no narratives depict the egg as having agency in the process (or even humorously being in control of it). The egg might be playfully depicted as giving directions to the sperm, choosing only one, and sucking the genetic material out of that sperm's head. Such a depiction would not be biologically accurate, but it would be somewhat analogous to the gentler narratives of sperm behavior in these videos. Yet, no egg-centric narrative is present, even in a humorous or satirical telling, in this media sample.

\section{Conclusion}

Through misrepresentation and under-representation in these videos, the role of the female body in reproduction is minimized or obliterated. Great importance is placed on the sperm's journey of traveling through the vagina to the fallopian tube to meet the egg; the sole actor in this tale of reproduction is the sperm. These absences reveal that the actual science of human fertilization is rendered irrelevant and less important than narratives that position males (sperm) as brave and powerful heroes fighting through unimaginable odds to win the prize 
(the egg). Biological accuracy is sacrificed in order to perpetuate an enduring cultural narrative of male heroes and conquerors who win females as passive prizes and trophies. These absences in representation symbolically annihilate the egg's role in fertilization and the female's role in reproduction and may reflect or even support cultural attitudes that the female voice in reproduction and reproductive choice should be secondary or silent. The enduring narrative of fertilization places power with the penetrator and not with the attractor. Conception is an act with no aggressor-on the cellular level at least. But that is not how the story is told.

\section{Acknowledgments}

The author thanks Mary Vavrus at the University of Minnesota for her encouragement; Ana Garner, Bonnie Brennan, and the Diederich College of Communication at Marquette University for support during the writing of this article; Emily Martin for the enduring inspiration of her work; and the anonymous reviewers, who helped add depth and nuance to the article. Sincere thanks to research assistants Aishwarya Shankar and Stephanie Walstrom.

Pamela Hill Nettleton is an assistant professor of journalism and media studies at Marquette University. She was a magazine writer and editor for thirty years before earning her doctorate. Her dissertation on post-9/I t television masculinity won the 2010 Kenneth Harwood Outstanding Dissertation Award from the Broadcast Education Association, and she recently won the 2014 Way-Klingler Award for Teaching Enhancement. She can be reached at pamela.nettleton@marquette.edu.

\section{References}

Againstfitna. 2008. "The Miracle of Human Creation." YouTube video, Io:Io. April 17. http://www.youtube.com/watch?v=6kGN2dcjNUY.

Akaraoo5. 2009. "Fertilization: A Sweet Love Story." YouTube video, 5:28. February 25. http://www.youtube.com/watch?v=Rfc684v3ZEs.

Armyofdar2monkeys. 2007. "3D Sperm Fertilization Project." YouTube video, I:40. December 2. http://www.youtube.com/watch?v=9MnQxiSJZ4Q.

BarfQuestion. 2007. "Sperm Rider: Quest for the Sky Egg." YouTube video, 3:08. February 4. http://www.youtube.com/watch?v=WY6nZoDsNJc.

Benkler, Yochi. 2006. The Wealth of Networks: How Social Production Transforms Markets and Freedom. New Haven, CT: Yale University Press.

bEx3d. 2008. "A Sperm's Eye View." YouTube video, I:27. March 2I. http://www.youtube $. c 0 m /$ watch? $v=a z F i E r 39 x B c$.

Bhujbal, Nachiket. 2oro. "Fertilization—an Epic Love Story." YouTube video, 2:5I. January I2. http://www.youtube.com/watch? $=$ Gou8OygOmpw.

Burgess, Jean, and Joshua Green. 2009. YouTube: Online Video and Participatory Culture. Cambridge: Polity Press. 
Chichin85. 2007. "Reproduction." YouTube video, 0:51. October 22. https://www.youtube .com/watch?v=t_eNmc_gHyE.

Cloud, Dana L. I992. "The Limits of Interpretation: Ambivalence and the Stereotype in Spencer: For Hire." Critical Studies in Mass Communication 9 (3): 31 I-24.

Condit, Celeste Michelle. 1989. "The Rhetorical Limits of Polysemy." Critical Studies in Mass Communication 6 (2): 103-22.

Condomz. 2006. "Why Use a Condom." YouTube video, o:34. December 6. http://www .youtube.com/watch?v=GuBvQceFzrw.

Conkey, Margaret W. 2008. "One Thing Leads to Another: Gendering Research in Archaeology." In Gendered Innovations in Science and Engineering, edited by Londa Schiebinger, 43-64. Palo Alto, CA: Stanford University Press.

Consalvo, Mia. 2003. "The Monster Next Door: Media Constructions of Boys and Masculinity." Feminist Media Study 3 (I): 27-45.

Cuklanz, Lisa M. 200o. Rape on Prime Time: Television, Masculinity, and Sexual Violence. Philadelphia: University of Pennsylvania Press.

DeLamater, John. 2007. "Gender Equity in Formal Sexuality Education." In Handbook for Achieving Gender Equity through Education, 2nd ed., edited by Susan S. Klein, Barbara Richardson, Dolores A. Grayson, Lynn H. Fox, Cheris Kramarae, Diane S. Pollard, and Carol Ann Dwyer, 4I I-20. Hillsdale, NJ: Lawrence Erlbaum.

Douglas, Mary. 1966. Purity and Danger: An Analysis of the Concepts of Pollution and Taboo. New York: Routledge.

Edmonds, Keith. 20I2. Dewhurst's Textbook of Obstetrics and Gynaecology, 8th ed. Oxford: Wiley.

Fausto-Sterling, Anne. 2000. Sexing the Body. New York: Basic Books.

Ferguson, Jill Hicks, Peggy J. Kreshel, and Spencer Tinkham. I99o. "In the Pages of Ms.: Sex Role Portrayals of Women in Advertising." Journal of Advertising I9 (I): 40-5I.

Fisher, Jill A. 20I I. Gender and the Science of Difference: Cultural Politics of Contemporary Science and Medicine. New Brunswick, NJ: Rutgers University Press.

Fiske, John. I987. Television Culture. London: Methuen, I987.

Garner, Ana, Helen M. Sterk, and Shawn Adams. I998. "Narrative Analysis of Sexual Etiquette in Teenage Magazines." Journal of Communication 48 (4): 59-78.

Gerbner, George. 1972. "Violence in Television Drama: Trends and Symbolic Functions." In Television and Social Behavior, vol. I: Media Content and Control, edited by George A. Comstock and Eli A. Rubinstein, 28-187. Washington, DC: USGPO.

Goldentusk. 20I2. "Sperm: The Easter Musical—Goldentusk." YouTube video, I:36. April 4. http://www.youtube.com/watch?v=IGzKJqPiswE.

Guineapigs. 2007. "Human Guinea Pigs—Sperm Race.” YouTube video, 2:15. December Io. http://www.youtube.com/watch?v=hyGKGNR8L6k.

Hacker, Neville F., Joseph C. Gambone, and Calvin J. Hobel. 2009. Hacker and Moore's Essentials of Obstetrics and Gynecology, 5th ed. Philadelphia: Saunders/Elsevier.

Hall, Stuart. 1975. "Introduction.” In Anthony C. H. Smith, Paper Voices: The Popular Press and Social Change, 1935-1965, II-24. London: Chatto and Windus.

- 1988. "New Ethnicities." In Black Film, British Cinema, edited by Kobena Mercer, 27-3r. London: Institute of Contemporary Arts.

—. 1992. "Race, Culture, and Communications: Looking Backward and Forward at Cultural Studies." Rethinking Marxism 5 (I): Io-I8. 
Hanke, Robert. 1998a. “The 'Mock-Macho' Situation Comedy: Hegemonic Masculinity and Its Reiteration." Western Journal of Communication 62 (I): 74-93.

. I998b. "Theorizing Masculinity with/in the Media." Communication Theory 8 (2): $183-203$.

Haraway, Donna J. 1989. Primate Visions: Gender, Race, and Nature in the World of Modern Science. New York: Routledge.

Hateworkboy. 2008. "A Let's Play Interim: You Have to Fertilize the Egg." YouTube video, I:58. July 3r. http://www.youtube.com/watch?v=GQtSow9tmIY.

Herman, Edward S., and Noam Chomsky. 1988. Manufacturing Consent: The Political Economy of the Mass Media. New York: Pantheon.

Hess, Aaron. 2009. "Resistance Up in Smoke: Analyzing the Limitations of Deliberation on YouTube." Critical Studies in Media Communication 26 (5): 4I I-34.

Hoerl, Kristen, and Casey Ryan Kelly. 2010. "The Post-Nuclear Family and the Depoliticization of Unplanned Pregnancy in Knocked Up, Juno, and Waitress." Communication and Critical/Cultural Studies 7 (4): 360-80.

Israelicommercials. 2008. "Winner Gambling-Sperm." YouTube video, o:33. September 4. http://www.youtube.com/watch?v=bPPjinK-zgo.

Izzo, Dan. 2009. "Fertilization Animation.” YouTube video, r:02. January 5. https://www .youtube.com/watch?v=qDf_KbTfqoA.

Jones, Julie Marie. 2010. "The Me in Media: A Functionalist Approach to Examining Motives to Produce within the Public Space of YouTube" (PhD diss., University of Minnesota).

Jones, Richard, and Kristin H. Lopez. 2006. Human Reproductive Biology, 3rd ed. Burlington, MA: Academic Press.

Katz, Jackson. I999. "Advertising and the Construction of Violent White Masculinity: From Eminem to Clinique for Men." In Gender, Race, and Class in Media: A Text-Reader, edited by Gail Dines and Jean M. Humez, 349-58. Thousand Oaks, CA: Sage Publications.

Kimmel, Michael. 20I . Manhood in America: A Cultural History. New York: Oxford University Press.

Klein, Susan Shurberg. 1988. "Sex Education and Gender Equity." Educational Leadership 45 (6): 69-75.

— Patricia E. Ortman, Patricia Campbell, Selma Greenberg, Sandra Hollingsworth, Judith Jacobs, Beatrice Kachunck, et al. I994. "Continuing the Journey Toward Gender Equity." Educational Researcher 23 (8): I3-2I.

Knobel, Michele, and Colin Lankshear. 20I0. "DIY Media: A Contextual Background and Some Contemporary Themes." In DIY Media: Creating, Sharing, and Learning with New Technology, edited by Michele Knobel and Colin Lankshear, I-26. New York: Peter Lang Publishing.

Knudsen, Britt T., and Carsten Stage. 2013. "Online War Memorials: YouTube as a Democratic Space of Commemoration Exemplified Through Video Tributes to Fallen Danish Soldiers." Memory Studies 7 (I): 418-36.

Maaxxximo. 2007. "Sperm." YouTube video, I:35. December i I. https://www.youtube $. \mathrm{com} /$ watch?v=XJFD 25 DcxLk

Martin, Emily. 199I. "The Egg and the Sperm: How Science Has Constructed a Romance Based on Stereotypical Male-Female Roles." Signs: Journal of Women in Culture and Society I6 (3): 485-50I. 
I992. "The End of the Body?" American Ethnologist I9 (I): I2I-40.

Mbarsoor. 2007. "ooSperm." YouTube video, 5:15. February 25. http://www.youtube.com /watch?v=FUZaiXZUYJ 4 .

Moore, Lisa Jean. 2008. Sperm Counts: Overcome by Man's Most Precious Fluid. New York: NYU Press.

Mulvey, Laura. 1975. "Visual Pleasure and Narrative Cinema." Screen i6 (3): 6-I8.

National Conference of State Legislatures. 20I4. "State Policies on Sex Education in Schools." http://www.ncsl.org/research/health/state-policies-on-sex-education-in -schools.aspx.

Nettleton, Pamela Hill. 2or I. "Domestic Violence in Men's and Women's Magazines: Women Are Guilty of Choosing the Wrong Men, Men Are Not Guilty of Hitting Women." Women's Studies in Communication 34 (2): 139-60.

Nucleus Medical Media. 20I2. "Fertilization (Conception)." YouTube video, 5:5I. July I I. http://www.youtube.com/watch?v=BFrVmDgh4v4.

Oreskovic, Alexei. 20I2. "YouTube Hits 4 Billion Daily Video Views." Reuters, January 23. http://www.reuters.com/article/20I2/or/23/us-google-youtube-idUSTRE8oMoTS 20120123.

Parents. 20I2. "Sperm Meets Egg." YouTube video, 2:47. September 6. http://www.youtube $. c 0 m /$ watch? $={ }^{2} \mathrm{vFf}$ Ls94iHc.

Parthenon Medical. 20I2. "Intrauterine Insemination-IUI-IUTPI. How the Sperm Met the Egg." YouTube video, 4:59. June I2. http://www.youtube.com/watch?v $=\mathrm{cXN}$ tfAhbdNs.

Proctor, Robert N., and Londa Schiebinger, eds. 2008. Agnotology: The Making and Unmaking of Ignorance. Palo Alto, CA: Stanford University Press.

Prushank, Diane T. 2007. "Masculinities in Teen Magazines: The Good, the Bad, and the Ugly." Journal of Men's Studies I5 (2): 160-77.

Rakow, Lana F. 200I. "Feminists, Media, Freed Speech." Feminist Media Studies I (I): $4 \mathrm{I}-44$.

Ralt, Dina, Mira Manor, Anat Cohen-Dayag, Ilan Tur-Kaspa, Izhar Ben-Shlomo, Amnon Makler, Izhak Yuki, et al. 1994. "Chemoaxis and Chemokinesis of Human Spermatozoa to Follicular Factors." Biology of Reproduction 50 (4): 774-85.

Redsandro. 2006. "Swim of the Sperm." YouTube video, o:23. October 12. http://www .youtube.com/watch?v=YYqnqr8X-Nw.

ReyMan2010. 2007. "Celebrity Sperm." YouTube video, o:I4. May i9. http://www.youtube .com/watch?v=YV2ZY8C_uLg.

Richardson, Sarah S. 2008. "When Gender Criticism Becomes Standard Scientific Practice: The Case of Sex Determination Genetics." In Gendered Innovations in Science and Engineering, edited by Londa Schiebinger, 22-43. Palo Alto, CA: Stanford University Press.

Richmond, Shane. 2or I. "YouTube Users Uploading Two Days of Video Every Minute." Daily Telegraph, May 26. http://www.telegraph.co.uk/technology/google/8536634 /YouTube-users-uploading-two-days-of-video-every-minute.html.

Robholio. 2008. "Sperm Attack." YouTube video, o:50. March 28. http://www.youtube .com/watch?v=PGrZZ7 Ef 2 fo.

Schiebinger, Londa. 1989. The Mind Has No Sex? Women and the Origins of Modern Science. Cambridge, MA: Harvard University Press. 
1993. Nature's Body: Gender in the Making of Modern Science. Boston: Beacon Press.

_. I999. Has Feminism Changed Science? Cambridge, MA: Harvard University Press.

- 2003. "Feminism Inside the Sciences." Signs: Journal of Women in Culture and Society 28 (3): 859-922.

- 2008. Gendered Innovations in Science and Engineering. Palo Alto, CA: Stanford University Press.

Seabrook, John. 20I2. "Streaming Dreams." New Yorker. January I6. http://www.new yorker.com/reporting/20I2/oI/I6/120I I6fa_fact_seabrook?currentPage=all.

SerenityNightwind69. 2007. "Failing Sperm." YouTube video, o:26. April 8. http://www .youtube.com/watch?v=zZ8hrLVvcB4.

Shibad, Sunil. 2009. "Sperm Race." YouTube video, o:38. October I6. http://www.youtube .com/watch?v=uIK-D_LQi8U.

Soaringxh3n. 2006. "Love=Sperm+Egg." YouTube video, o:I2. February Io. http://www .youtube.com/watch?v=WERkvpk-bIY.

SuperPikaGrox. 2009. "The Great Sperm Race Part I Vagina.wmv." YouTube video, I:39. December I2. http://www.youtube.com/watch?v=jrotftiXDUc.

Teencompanion. 2008. "Human Fertilization." YouTube video, 4:2I. September 3. http:// www.youtube.com/watch?v=vXNaTRs83hE.

Tuchman, Gaye. 1978. "Introduction: The Symbolic Annihilation of Women by the Mass Media." In Hearth and Home: Images of Women in the Mass Media, edited by Gaye Tuchman, Arlene Kaplan Daniels, and James Benit, 3-38. New York: Oxford University Press.

Vadg. 2009. "From a Sperm to an Egg—with Love." YouTube video, o:24. February I3. http://www.youtube.com/watch?v=TDW28qWBhzc.

Van Dijck, José. 2009. "Users Like You? Theorizing Agency in User-Generated Content." Media, Culture Eु Society 3I (I): 4I-59.

YouTube. 20Io. Policy Center. https://www.youtube.com/yt/policyandsafety/policy.html. Zuccarello, Daniela, Alberto Ferlin, Andrea Garolla, Massimo Menegazzo, Lisa Perilli, Guido Ambrosini, and Carlo Foresta. 20r r. "How the Human Spermatozoa Sense the Oocyte: A New Role of $\mathrm{SDF}_{\mathrm{I}}-\mathrm{CXCR}_{4}$ Signalling." International Journal of Andrology 34 (6, pt. 2): e554-65. 